UDC 329(497.11)“18“

Милош Савин

Оригинални научни рад

Универзитет у Новом Саду

примљено: 15. мај 2011

Докторант

прихваћено: 1. октобар 2011

milsavin@gmail.com

\title{
СТАВОВИ СРПСКИХ ЛИБЕРАЛА ИЗ УГАРСКЕ О СРПСКО-БУГАРСКОМ РАТУ
}

Сажетак: Милетићева српска народна слободоумна странка се 1884. диференцира на три фракције: „Нотабилитетску“, радикалну и либералну. Српски либерали Угарске се окупљају око часописа Браник чије оснивање 1885. коинцидира са предратном кулминацијом односа Србије и Бугарске. Србијански краљ Милан и шеф напредњачке владе Милутин Гарашанин, незадовољни уједињењем Бугарске, без храбрости и подршке да траже обештећење на рачун Турске, покрећу рат против Бугарске, чији циљ није заузимање бугарских територија, већ враћање Балкана у претходно стање. Српски либерали из Угарске, Миша Димитријевић, Паја Јанковић и Никола Јоксимовић, критикују тежњу Србије да ратује против Бугарске, сматрају праведном надокнадом заузимање Македоније и Старе Србије. Када до рата ипак дође, апелују на Српство да буде солидарно са српском војском. Након српског пораза, бугарског заузимања Пирота и примирја које је издејствовала Аустроугарска, сматрају да је излаз из ситуације наставак борбе, победа и одбијање аустроугарског мешања. У периоду између почетка примирја 28. новембра 1885. па до потписивања мира 3. марта 1886. долази до интензивне политичке акције у Србији. Краљ иницира први контакт са вођом опозиционих србијанских либерала Јованом Ристићем, након чега српски либерали из Угарске оштрицу својих речи фокусирају на Гарашанина и напредњаке, постепено аболирајући одговорности краља - како би направили одступницу за евентуалну владу себи блиске либералне партије у Србији.

Кључне речи: либерали, Браник, Српство, Србија, Бугарска, Аустроугарска, Русија, Миша Димитријевић, Паја Јанковић, Никола Јоксимовић, краљ Милан, Милутин Гарашанин, Александар Батенберг.

Српска народна слободоумна странка Светозара Милетића, односно, Српска народна либерална странка како се често називала а како се и данас неретко назива у историографији, због изворно либералног програма и изједначавања појма 
слободоуман и либералан, представљала је почетком осамдесетих година деветнаестог века општенародни скоро дезидеологизовани српски покрет. Након Милетићеве пасивизације услед болести, долази до диференцијације три политичке струје у вези са Бечкеречким програмом. Део странке тзв. „Нотабилитети“ 1884. усвајају Великокикиндски програм, знатно умањујући српске захтеве и на фону реалне политике идеолошки се приближавају угарској владиној странци. Акционо јединство противника Великокикиндског програма се наредних годину дана цепа на две групе. Прву групу чине народњаци окупљени око Јаше Томића и Лазе Нанчића, који су још за време Милетићевог вођства ушли у спор са њим тражећи допуну Бечкеречког програма питањем хлеба, тј. додавањем одређених социјалистичких програмских начела; ова група ће временом прерасти у Српску народну радикалну странку. Другу групу чине либерали који се противе било каквим променама и допунама Бечкеречког програма. На челу ове групе, до повратка Михајла ПолитДесанчића у политику 1887. и званичног конституисања странке, налази се шајкашки посланик на Угарском сабору Миша Димитријевић, у друштву Илије Вучетића, Николе Јоксимовића, Паје Јанковића и других. Димитријевићева односно Политова фракција ће све време постојања задржати назив Српска народна слободоумна странка држећи се декларативно Бечкеречког програма и чисте народно-либералне политичке платформе. Историјском конвенцијом, од 1884. можемо групу, фракцију, односно странку коју су у првом реду представљали Миша Димитријевић и Михајло Полит-Десанчић (од 1887) назвати Српском либералном странком. Поред идеолошке долази и до персоналне конфронтације либерала и радикала приликом избора за Новосадску црквено-народну општину, преузимања старог милетићевског гласила Заставе из руку „Нотабилитета“ од стране Томића, након формирања либералне већине и Томићевог враћања мандата у црквенонародном сабору и оснивања листа Браник од стране Мише Димитријевића.

Тема овог чланка је искључиво однос српских либерала у Угарској, окупљених у конкретном историјском тренутку око листа Браник, према српскобугарском рату $1885 / 86$. године.

Пред избијање српско-бугарског рата 1885. године, Србија, осносно „Земља чуда“" како су је често називали српски либерали из Угарске, налазила се у деликатним унутрашњополитичким и геополитичким околностима. Србијом је владао комплетни краљев апсолутизам упркос формално постојећем правном поретку $^{1}$, као и потпуна аустрофилија - која је превазишла фазу геополитичких интереса, прерастајући у личну опсесију краља Милана. ${ }^{2}$ Непуних месец дана пре објаве рата Бугарској, тадашњи вођа српских либерала и њихов заступник у угарском сабору Миша Димитријевић формулише српски народно-либерални став: „Према суседној краљевини Србији заступаћемо све оно, што њеном унутрашњем ојачању и њеној спољашњој самосталности и независности у прилог иде. Од свију данас тамошњих странака држимо да овоме програм тамошње Либералне странке

\footnotetext{
${ }^{1}$ Историја српског народа (шеста књига, први том), Од Берлинског конгреса до уједињења 1878-1918, Београд 1983, 75.

${ }^{2}$ Исто, 77.
} 
највише одговара“. ${ }^{3}$ Став српског слободоумног првака из Угарске недвосмислено пркоси тадашњем апсолутизму и аустофилији краља и владе у Србији. Либерална странка у Србији није претрпела интензиван прогон, попут радикала, али је као бескомпромисна опозиција била у немилости власти.

Поред значајних концепцијских разлика у жељи за проширењем на рачун Турске, у којима је Русија судећи по Санстефанском уговору давала предност Бугарима ${ }^{4}$, између Србије и Бугарске је већ дуже време расла тензија, пре свега због благонаклоности Бугарске према српским емигрантима (радикалима, после пропасти Тимочке буне), који су вршили антивладину агитацију са пограничне бугарске територије, као и због поседа код Брегова на Тимоку који је променом тока те реке прешао на турску, касније бугарску страну границе. ${ }^{5}$ У тренутку најнапетијих односа између Бугарске и Србије, бугарски родољуби свргавају у Пловдиву турског гувернера, ослобађају Источну Румелију што доводи до уједињења Бугарске 18. септембра 1885. Бугарска је увећана на рачун Турске, у оквиру свог етничког простора, не задирући у подручја на која је претендовала и Србија. Краљ Милан је са својом камарилом, уместо да у легализацији бугарског уједињења види прилику за компензацију према Србији и српско ширење на рачун територија које су још биле под турском окупацијом, убрзао припреме за рат против Бугарске, у којој је видео смртну опасност по српске интересе. ${ }^{6}$ Страхујући од турске војне снаге, Милан је одбацио помисао о кретању у правцу Македоније. ${ }^{7}$

Српски либерали у Угарској трезвеније виде ситуацију на Балкану, те у свом гласилу истичу: „Ми дубоко жалимо, да брат на брата диже руку. Ми држимо да пут Српске војске није у Софију већ у Стару Србију.“8 Поред очигледног неслагања са политиком краља Милана и напредњачке владе, родољубље им не дозвољава да окрену леђа „српском Пијемонту“, што истичу у ставу „Ако баш мора бити српско-бугарског рата, држимо, да не сме бити ни једног Србина, који ће правити сметње Србији.“9 Националну солидарност српских либерала Угарске најбоље илуструје реченица: „Ми смо у првом реду Срби, па онда Словени, а у оваквим приликама тек у последњем реду - политичари.“10

„Гордијевом чвору“ који је очигледно превазишао могућност перцепције геополитичких односа краља Милана и политички безличног опортунисте Милутина Гарашанина ${ }^{11}$, допринео је и читав сплет међународних односа. Русија која је прва иницирала бугарско уједињење у овом тренутку нија била на тим позицијама - није јој одговарала личност антируског „бугарског“ кнеза Александра

\footnotetext{
${ }^{3}$ Браник, бр. 1, 17. октобар 1885.

${ }^{4}$ Слободан Јовановић, Влада Милана Обреновића, део II, Београд 1990, 232.

${ }^{5}$ Владимир Ћоровић, Историја Срба, Београд 2005, 410.

${ }^{6}$ Историја српског народа, 79.

${ }^{7}$ Слободан Јовановић, нав. дело, 235.

${ }^{8}$ Браник, бр. 2, 20. октобар 1885.

${ }^{9}$ Исто.

${ }^{10}$ Исто

${ }^{11}$ Историја српског народа, 76.
} 
Батенберга, рођака енглеске краљице Викторије ${ }^{12}$, који је на сваки начин покушавао да докаже да Бугарској не треба руска подршка. Руски официри и војни саветници су повучени из Бугарске. Аустроугарска се није залагала за бугарско уједињење, али га је прихватила као свршен чин, и није имала интерес да учини било шта против тога. Српски либерали у Угарској свеснији ситуације почињу да се изразито антибугарски изјашњавају и постављају питање обештећења, односно права на територијално проширење Србије и Грчке због уједињења Бугарске, али науштрб Турске. $^{13}$

Либералски Браник у својим текстовима брани право Србије да буде обештећена, али критикује неконтролисану бугарофилију хрватског јавног мнења „пало нам је у очи, да се наша браћа Хрвати јако симпатишу са Бугарима“ 14 , констатујући да „премда су и Бугари унеколико криви, Хрвати су сасвим на страни бугарској“. 15

Један од најистакнутијих и најактивнијих српских либерала из Угарске у том периоду Паја Јанковић, поредећи, индиректно, покушаје помађаривања и стварања ,једног политичког народа“ у Угарској са ситуацијом на Балкану, запажа да се неке „државе труде да од својих грађана вештачки створе један народ, а и то да народи теже да се у једној народној држави уједине“. ${ }^{16}$ Поредећи метод формирања држава на принципу народне тежње да створи уједињену народну државу и други кад државе накнадно вештачки створе свој народ, за први начин закључује да ,је природан и истинит, а други неприродан и лажан“. ${ }^{17}$ Јанковић истиче да „Остварење начела о народној држави видимо и у најновијој кризи на балканском полуострву, то начело је руководило Бугаре при присаједињењу Румелије; а и Србија и Грчка ништа друго не траже и не могу тражити, него да и оне присаједине српске и грчке земље“. ${ }^{18}$ Јанковић верује да су супротности и анимозитети између Бугара, Хрвата и Срба изазване вештачким путем од стране непријатеља и да Хрвати и Бугари треба то да схвате и врате се слози. Међутим, оштро се противи хрватским тезама да су Срби и Хрвати (па и Бугари) један народ. $^{19}$ У овоме види покушај асимилације Срба у Хрватској (и Македонији). Доследно бранећи принцип права народа да се уједини, Јанковић каже: „Ми би јако жалили кад би Србија била поводом да се Бугарска не уједини, као што би жалили да због Бугарске Србија претрпи огромну материјалну штету...“20 Међутим, овај знаменити српски либерал остаје непоколебљив - „Али ни за један моменат не би могли бити у двојби на кога да бацимо кривицу због ових жалосних

\footnotetext{
${ }^{12}$ Владимир Ћоровић, нав. дело, 412 .

${ }^{13}$ Браник, бр. 8, 3. новембар 1885.

${ }^{14}$ Браник, бр. 6, 29. октобар 1885.

${ }^{15}$ Исто.

${ }^{16}$ Браник, бр. 9, 5. новембар 1885.

${ }^{17}$ Исто.

${ }^{18}$ Исто.

${ }^{19}$ Браник, бр. 10, 7. новембар 1885.

${ }^{20}$ Браник, бр. 9, 5. новембар 1885.
} 
резултата“. ${ }^{21}$, „Ми би бацили кривицу у првом реду на Берлински уговор а у другом на ненародну политику бугарских шовиниста“. ${ }^{22}$

Своју анализу србијанско-бугарских односа Јанковић враћа у призму Миланове аустрофилске политике и безрезервног ослањања на Аустроугарску, као и дволичне аустроугарске политике према Србији, запажајући следеће: „Не може се знати је ли Србија мобилизирала војску у споразуму са Аустријом, али да је Србија рачунала и рачунати могла на потпору аустријску, потврдио је говор Тисин у угарском сабору“. ${ }^{23}$

Занимљиво је да став српских либерала у Угарској поводом већ извесног српско-бугарског рата иритира владине кругове у Србији. Тако београдски лист Видело оптужује Србе у Угарској, а на првом месту Димитријевићев либералски Браник за бугарофилију и антисрпство. У одговору једног од најистакнутијих српских либерала Угарске, одговорног уредника Браника Илије Јоксимовића, садржана је есенција политичког става који заузимају српски либерали Угарске: „Врло добро знамо да Бугари нису невини јагањци. Али зато не можемо да одобримо све што ради Српска влада“, ${ }^{24}$, „е бранимо Бугаре; добро знамо да је у српско-бугарском рату сваки Србин обавезан да морално подупире Србију, али док се не огласи рат, дужност нам је да кажемо, да овај рат неће уродити добрим плодом“. 25

Увидевши да драстичних мера великих сила према Бугарској неће бити, краљ Милан је 14. новембра 1885. објавио рат Бугарској. Миша Димитријевић је одмах критички одреаговао: „Међу суседима словенским, међу браћом рођеном, међу Србима и Бугарима, букнуо је ужасни крвави рат.“26 „Али уз данашњу убојну трубу не чујемо ми тај клик одушевљења. Нити га чујемо нити га сами осећамо.“27,Је ли овај рат бар ичим оправдан? Је ли он нужна коректива поремећених суседних одношаја? Је ли Бугарска завитлала убојно оружије на своју сестру Србију? Ми од свега тога ништа не видимо.“28 „Зар малена краљевина Србија, тај српски Пијемонт, нема истоветне тежње уједињења и проширења?“29 „Но ми нећемо да свалимо цео терет одговорности на саму Србију. Велики део овог терета носи и Бугарска.“30 Међутим, остајући непоколебљив у свом родољубљу, Димитријевић закључује: „Је ли овај озбиљан покрет руководила српска мисао или није, да ли је српске јунаке испратило на бојно поље одушевљење народа, или је све то дело више политике, па су синови земље по својој поданичкој дужности морали да пођу преко границе - није сада питање.“31 „Срби на осталим крајевима које није

\footnotetext{
${ }^{21}$ Исто.

${ }^{22}$ Браник, бр. 9, 5. новембар 1885.

${ }^{23}$ Браник, бр. 11, 10. новембар 1885.

${ }^{24}$ Исто.

${ }^{25}$ Браник, бр. 13, 14. новембар 1885.

${ }^{26}$ Браник, бр. 14, 17. новембар 1885.

${ }^{27}$ Исто.

${ }^{28}$ Исто.

${ }^{29}$ Исто.

${ }^{30}$ Исто.

${ }^{31}$ Браник, бр. 15, 19. новембар 1885.
} 
притисла ратна невоља, треба да се нађу пострадалим борцима српским на невољи“. 32

У циљу развијања најшире солидарности са српском војском, с обзиром да je очигледно да се закаснило са мирним решењем, либералски Браник истиче: „Нужно је да српска војска што пре доконча овај рат. ““33 „Како су се развиле ствари, сваки Србин мора желети победу српском оружију, иначе за Србију нема излаза из овог ћор-буџака“. ${ }^{34}$ „Садашња Политика Србије то је нешто прелазно, важност Србије, то је нешто стално. А највећа несрећа би била да Србија буде потучена, јер уколико буде она слабија, утолико је више упућена да тражи туђу помоћ и заштиту“. ${ }^{35}$

Услед лоше команде, тактике и читавог планирања овог непотребног сукоба, ратно клатно се са Бугарске пребацило на територију Србије - након пораза код Сливнице у Бугарској, лоше командована, обезглављена и деморалисана српска војска изгубила је и Пирот у Србији. Одмах потом, 28. новембра Аустроугарска је енергичним посредовањем (претњом да ће аустроугарска војска ући у Србију, а руска у Бугарску) издејствовала код бугарског кнеза примирје - које је суштински представљало и крај рата. ${ }^{36}$ Веома је занимљив и један од аустроугарских аргумената предочених бугарском кнезу - велико узнемирење српског становништва Хабзбуршке монархије. ${ }^{37}$ Званичан мировни уговор између Србије и Бугарске је потписан тек 3. марта 1886.

Српски либерали у Угарској су се од почетка противили оваквом авантуризму владајуће камариле у Србији, а целокупна политика Србије у том периоду била је супротна српским либералним начелима које је према краљевини Србији истакао Миша Димитријевић - на првом месту: унутрашње ојачање и спољашња самосталност и независност. Пораз, аустроугарско посредовање и заштита, измољено примирје, другим речима национална срамота, за српске либерале у Угарској је била неприхватљива - Браник о томе пише: „Пораз српске војске још није пораз српске државе, до меродавних фактора у Србији стоји да се ове погрешке изгладе како то интереси српства захтевају“, 38 „Дужност Србије је да прекрати примирје, да рат обнови и да аустријско наметање одбије на најдостојнији начин. Бугари у Пироту а Аустрија да их тера из Пирота - не то није згодан тренутак који би годио Србији“. ${ }^{39}$ Не кријући огорчење према србијанској влади, Никола Јоксимовић ламентира: „Тешко је што су Бугари у Пироту, још теже је што су српски државници слаби, најтеже је што покровитељ помаже. Свему томе треба да народ у Србији учини крај““. ${ }^{40}$ Не мирећи се са поразом Србије у рату против ког

\footnotetext{
${ }^{32}$ Браник, бр. 15, 19. новембар 1885.

${ }^{33}$ Браник, бр. 17, 24. новембар 1885.

${ }^{34}$ Исто.

${ }^{35}$ Браник, бр. 18, 26. новембар 1885.

${ }^{36}$ Историја српског народа, 83.

${ }^{37}$ Слободан Јовановић, нав. дело, 271.

${ }^{38}$ Браник, бр. 19, 28. новембар 1885.

${ }^{39}$ Браник, бр. 21, 3. децембар 1885.

${ }^{40}$ Исто.
} 
је био, запажа да „Велика Бугарска под оваквим приликама опаснија је за Србију а и за дужи мир на истоку, јер ће Бугарска тек после овог рата имати маха за агитацију“41, и закључује: „Неуспех српског оружја убрзао је уједињење Бугарске“. ${ }^{42}$ Помало се наивно нада да ће доћи до извесног преокрета: „Ако Србија продужи рат и буде успешно нападала, њено ће се стање побољшати“43.

Поред дипломатске активности, пре свега великих сила, у периоду између почетка примирја 28. новембра 1885. и потписивања мира 3. марта 1886. дошло је и до интензивних политичких активности у самој Србији. ${ }^{44}$ До првог контакта краља Милана и либералског вође Јована Ристића дошло је 24. децембра. Већ у иступима српских либерала у Угарској од 26. децембра приметно је намерно диференцирање краља и Гарашанина, како би се оставила отворена врата за договор краља са Ристићем, што је у складу са програмским начелима према краљевини Србији које је у првом броју Браника формулисао Миша Димитријевић, посебно у реченици: „Од свију данас тамошњих странака држимо да овоме програм тамошње Либералне странке највише одговара““.

Браник српских либерала у Угарској већ 26. децембра 1885. враћа балкански проблем на питање геополитике и односа великих сила и равнотеже на Балкану, понављајући почетну тезу, коју су српски либерали из Угарске, одмах након бугарског уједињења презентовали наводећи следеће: „Ако се призна велика Бугарска, треба да се повећа и Србија.“45 Понављајући да то може бити учињено „само на рачун Турске, да ће Србија морати да уђе у Стару Србију и Мацедонију“. ${ }^{46}$ Плашећи се нестабилности и угрожености династије у Србији, а извесно знајући за контакте Јована Ристића, вође србијанских либерала, и краља у циљу смене Гарашаниновог кабинета, Браник постепено аболира и краља Милана казујући: „Свако насилно рушење постојећег стања у Србији држимо да је непатриотично и противно српској мисли“ “47, „Нека Србија буде јака нека добије накнаду, нека заузме некадашње српске земље, па кад то учини, онда нека се врати на унутрашња питања и нека ради што за добро нађе“, 48 „Прво прикупите раскомадане делове српства, уђите у Призрен, па онда мењајте краља ако вам овај није по вољи“. ${ }^{49}$

У дефинисању одговорности, али на начин да се отворе врата разговорима србијанских либерала са краљем, српски либерални првак из Угарске Паја Јанковић поново погађа у центар, прецизним и убојитим речима: „Шта дакле још хоће ти напредњаци? Хоће ли још и даље да срамоте Србију, да срамоте цело Српство? Зар Гарашанин сме и да буде у Србији коју је тако љуто осрамотио, а некамоли и даље да седи у фотељи министра председника. Зар краљ Милан заиста хоће да веже своју

\footnotetext{
${ }^{41}$ Браник, бр. 23, 8. децембар 1885.

${ }^{42}$ Исто.

${ }^{43}$ Исто.

${ }^{44}$ Слободан Јовановић, нав. дело, 285.

${ }^{45}$ Браник, бр. 31, 26. децембар 1885.

${ }^{46}$ Исто.

${ }^{47}$ Исто.

${ }^{48}$ Исто.

${ }^{49}$ Исто.
} 
судбину за напредњаке? Зар он баш силом жели да изазове грађански рат због ових јадника?“, 50 „Грађанског рата данас у Србији не сме бити“, ${ }^{5}$ „Нека краљ Милан добро поразмисли о положају свом тако и положају Србије, отаџбине своје“, 52 „Нека се не везује са онима који морају пасти, него нека учини сам оно, што би иначе морала Србија учинити. Нека одбаци од себе напредњачку уиту, ту срамоту целог српства“. 53

Миша Димитријевић, аналитично и интелигентно у свом маниру, као неспорни идеолог српских либерала тог периода постепено релаксира фактички, али још увек не и формално, завршени српско-бугарски рат геополитичком анализом: „Када би велесиле ствар источног питања са гледишта источних народа посматрале, онда би се брзо нашао излаз из данашњих заплета“, 54 „Балкански полуострв је магазин убојног материјала. Једна искра, једна варница, довољна је па да цела зграда одједампут у пламен букне“. 55

Након формалног потписивања српско-бугарског споразума, орган српских слободоумаца износи своју анализу, генерализујући претходне догађаје и новонасталу ситуацију, али чврсто стојећи на бранику својих досадашњих ставова „И козу су пренели и курјака су превели и спасили купус“, 56 „Мир је међу Србијом и Бугарском Склопљен. Но после овог мира неће потећи мед и млеко на балканском полуотоку“, 57 „Ми поздрављамо мир који је закључен међу Србијом и Бугарском и желимо, да он буде претеча српско-бугарског пријатељства и слоге источних народа, и да никад не дођу у тај сраман положај да их Европа мири, а Турска да им натурује пријатељство“. ${ }^{58}$

Извори и литература:

Извори:

Браник, бр. 1, 2, 6, 8, 9, 10, 11, 13, 14, 15, 17, 18, 19, 21, 23, 31, 33, Нови Сад 1885.

Браник, бр. 4, 21, Нови Сад 1886.

Литература:

Попов, Чедомир, et.al, Историја српског народа VI-1, Од Берлинског конгреса до ујединјења 1878-1918, Београд 1983.

Слободан, Јовановић, Влада Милана Обреновића II, Београд 1990.

Владимир, Ћоровић, Историја Срба, Београд 2005.

\footnotetext{
${ }^{50}$ Браник, бр. 33, 31. децембар 1885.

${ }^{51}$ Браник, бр. 31, 26. децембар 1885.

${ }^{52}$ Исто.

${ }^{53}$ Исто.

${ }^{54}$ Браник, бр. 4, 23. јануар 1886.

${ }^{55}$ Исто.

${ }^{56}$ Браник, бр. 21, 4. март 1886.

${ }^{57}$ Исто.

${ }^{58}$ Исто.
} 


\title{
STANDPOINTS OF SERBIAN LIBERALS FROM HUNGARY OF SERBO-BULGARIAN WAR
}

\begin{abstract}
Summary
Serbian liberal party in Hungary was divided into three fractions in 1884: Conservative, Radical and Liberal. Conservatives accepted a new program in Kikinda which made them closer to the Hungarian government. Radicals wanted to keep the old "Beckerek program", but they also wanted to supplement it with some socialist ideas. Liberals, as a continuing political party, kept the name Serbian Liberal Party until the end of their existence and they held on to declarative "Beckerek program" and pure national and liberal political platform. From 1885, Serbian liberals from Hungary gathered around "Branik" magazine, which foundation coincided with prewar culmination of relations between Serbia and Bulgaria. There was a dispute between Serbia and Bulgaria due to Serbian emigrants, who escaped to Bulgaria after the failure of mutiny and agitated against the ascendancy of Serbian Kingdom from Bulgarian bordering areas. Moreover, the Timok River changed its course, so that a minor Serbian property near Bregovo belonged to Bulgaria. Russia's earlier plans were to create "The Grat Bulgaria”, including some Turkish territories which Serbia claimed to it. The duke Aleksandar Betenberg ruled Bulgaria. Russians were against him, and Austrians were on the side of the Serbian government that was supporting Austria. There was a sudden amalgamation of Bulgaria in September 1885, when the Bulgarian patriots in the province of Eastern Rumelija deprived the Turkish governor of his duties. King Milan of Serbia and the chief of progressive government, Milutin Garašanin, were dissatisfied with Bulgarian amalgamation and had neither courage, nor support to get compensation from Turkish territories. Therefore they started a war against Bulgaria, which cause was not taking Bulgarian territories, but returning the Balkans into the previous state. Serbian Liberals from Hungary, Miša Dimitrijević, Paja Janković and Nikola Joksimović, criticized Serbia's will to begin the war against Bulgaria. They considered Serbia taking Macedonia and Old Serbia to be a fair compensation. Although Serbian Liberals in Hungary were against Serbo-Bulgarian war, they thought that if the war began nevertheless, all Serbs should give their support to it. Serbian Liberals criticized Croatian public which had shown that they were greater sympathizers of Bulgaria than of Serbia. The Liberals answered false accusations of Belgrade newspapers that they supported Bulgaria. When the war began, they appealed to the entire Serbian population to be supportive of Serbian army. After Serbia's defeat, Bulgarian taking over of Pirot and truce that was due to Austro-Hungarian Empire, Serbian Liberals in Hungary considered continuation of fight, victory and declining of Austria's interference to be the way out of the situation. In the period between the beginning of the truce on November 28, 1885 and the ratification of the peace on March 3,
\end{abstract}


1886, there was an intensive political action in Serbia. The king made the first contacts with the leader of the opposing Liberals in Serbia, Jovan Ristic, who made the Serbian Liberals from Hungary to focus their speeches and critics both on Garasanin's politics and the government of Progressive Party. That way they enabled the abolition of the king's responsibilities in order to make a fallback for potential government of the political party in Serbia with similar goals.

Keywords: Liberals, Branik, Serbian attitude, Serbia, Bulgaria, Austro-Hungary, Russia, Miša Dimitrijević, Paja Janković, Nikola Joksimović, the King Milan, Milutin Garašanin, Aleksandar Batenberg. 